\title{
The Alterations in Methylene Blue/ Light-Treated Frozen Plasma Proteins Revealed by Proteomics
}

\author{
Tiange $\mathrm{Wu}^{\mathrm{a}}$ Xiaoning Wang ${ }^{\mathrm{b}}$ Kai Ren ${ }^{\mathrm{a}}$ Xiaochen Huang ${ }^{\mathrm{c}}$ Jiankai Liu ${ }^{\mathrm{d}}$ \\ ${ }^{a}$ Blood Transfusion Department, The Second Hospital of Jilin University, Changchun, China; ${ }^{b}$ Blood Transfusion \\ Department, The First Hospital of Jilin University, Changchun, China; ${ }^{\mathrm{C}}$ Anesthesiology, Changchun University \\ of Chinese Medicine, Changchun, China; d Department of Biochemistry, College of Basic Medical Sciences, Jilin \\ University, Changchun, China
}

\section{Keywords}

Fresh frozen plasma. Methylene blue/light-treated frozen plasma - Mass spectrometry · Keratin - Type II cytoskeletal 1 . Hemopexin

\begin{abstract}
Introduction: The aim of this study was to investigate the modified proteins in methylene blue/light-treated frozen plasma (MB-FP) compared with fresh frozen plasma (FFP) in order to gain a better application of $\mathrm{MB}$ /light-treated plasma in clinic transfusion. Methods: MB-FP and FFP were collected from Changchun central blood station, and a trichloroacetic acid/acetone precipitation method was used to remove albumin for the enrichment of lower abundance proteins. The plasma protein in MB-FP and FFP were separated using twodimensional gel electrophoresis (2-DE) and the differentially expressed protein spots were analyzed using mass spectrometry. Finally, the differentially expressed proteins were tested using Western blot and enzyme-linked immunosorbent assay (ELISA). Results: Approximately 14 differentially expressed protein spots were detected in the MB-FP, and FFP was chosen as the control. After 2-DE comparison analysis and mass spectrometry, 8 significantly differentially expressed protein spots were identified, corresponding to 6 different proteins, including complement $\mathrm{C} 1 \mathrm{r}$ subcomponent (C1R), inter-alpha-trypsin inhibitor heavy chain H4 (ITI$\mathrm{H} 4)$, keratin, type II cytoskeletal 1 (KRT1), hemopexin (HPX), fibrinogen gamma chain (FGG), and transthyretin (TTR).
\end{abstract}

karger@karger.com www.karger.com/tmh

Karger ${ }^{\prime \prime} \%$ BOPEN ACCESS
(C) 2021 The Author(s)

Published by S. Karger AG, Basel

This is an Open Access article licensed under the Creative Common Attribution-NonCommercial-4.0 International License (CC BY-NC) (http://www.karger.com/Services/OpenAccessLicense), applicable to the online version of the article only. Usage and distribution for commercial purposes requires written permission.
Western blot showed no significant difference in the expression level of KRT1 between MB-FP and FFP $(p>0.05)$. Both Western blot and ELISA indicated that the level of HPX was significantly higher in FFP than in MB-FP $(p<0.05)$. Conclusion: This comparative proteomics study revealed that some significantly modified proteins occur in MB-FP, such as C1R, ITI-H4, KRT1, HPX, FGG, and TTR. Our findings provide more theoretical data for using MB-FP in transfusion medicine. However, the relevance of the data for the transfusion of methylene blue/light-treated plasma remains unclear. The exact modification of these proteins and the effects of these modified proteins on their functions and their effects in clinical plasma infusion need to be further studied.

(C) 2021 The Author(s)

Published by S. Karger AG, Basel

\section{Introduction}

Blood transfusion is a life-saving treatment for patients with severe blood loss due to various surgeries, trauma, or other clinical conditions [1]. With the continuous development of modern medicine, transfusion of whole blood, through unknown causes, may lead to circulatory overload, increased metabolic burden, and induced isoimmunity in patients, which may result in different degrees of transfusion immune response or adverse consequences in further transfusion treatment and rescue [2]. Therefore, nowadays, modern transfusion 
medicine advocates blood component transfusion where doctors selectively inject different types of blood components according to the patient's conditions [3].

Essential for blood component transfusion, plasma has been reported to play vital roles in clinical therapy (especially in intensive care and the treatment of kidney and/or hematology diseases), but it also increases the risk of transfusion-transmitted infectious diseases [4]. According to the British Society of Haematology Guidelines, fresh frozen plasma (FFP) is mainly used for the following 3 indications: prevention of bleeding (prophylaxis), hemostasis (treatment), and plasma exchange. Preventive blood transfusion is mainly performed before surgery or invasive procedures, and a large volume of trial data suggest that the use of FFP in many patients is only indicated when major bleeding occurs. For all individuals born after January 1, 1996, pathogen-inactivated plasma is recommended because the associated risk of infection with known test viruses is very low $[5,6]$. The safety of blood donation has been improved through quarantine, but due to the incubation period of potential pathogens, there is still a risk for infection transmitted by blood transfusion. In any case, plasma must be safe for transfusion, especially in the situation of emerging viral pathogens that may threaten blood recipients (such as SARS-CoV-2). Several different pathogen-reduction technologies (PRT) have been adopted to reduce or prevent the spread of blood pathogens in plasma. PRT can effectively compensate for virus test defects caused by the incubation period of certain virus infections, and have been used to treat blood components and products for decades. The main processes of PRT include the use of solvent detergents, methylene blue (MB), amotosalen, and riboflavin as additives [7-10]. The most commonly used method is solvent detergents or MB. MB can bind to nucleic acids, especially G-C base pairs of the virus DNA, and MB/light treatment can result in broken DNA strands [11]. Previous studies have shown that MB can effectively inactivate viruses in plasma when exposed to light $[12,13]$. Additionally, plasma after $\mathrm{MB} /$ light pathogen inactivation can relieve blood transfusion reaction to a great extent and is widely used in the clinic. The literature suggested that $\mathrm{MB} /$ light treatment can reduce the levels of several coagulation factors and their clotting ability, but still at acceptable levels $[14,15]$. In addition, $\mathrm{MB} /$ light treatment is reported to reduce the coagulation capacity of FFP in vitro, likely due to additional freezing and thawing procedures and photooxidation-induced protein damage $[16,17]$. In clinical settings, untreated FFP is preferred for patients with hemorrhage lacking clotting factors. More caution is needed when using any blood products in newborns and young children because they may develop blood transfusion complications later in life. Therefore, newborn patients are more likely to be provided with
MB-treated plasma. However, in addition to blood coagulation factors, other changes in plasma protein components between $\mathrm{MB} /$ light-treated frozen plasma (MBFP) and FFP still need to be explored. Through proteomics, Crettaz et al. [18] found that MB treatment resulted in alterations of fibrinogen gamma chain (FGG), transthyretin (TTR), and apolipoprotein A-1.

In order to confirm the results of Crettaz et al. [18] and discover potentially novel plasma protein changes through proteomics, this study uses two-dimensional gel electrophoresis (2-DE) to separate the plasma proteins of FFP and MB-FP, and uses mass spectrometry to analyze the spots of significantly differentially expressed protein between MB-FP and FFP. In addition to the reported changes in coagulation factors, the results of this study will also provide an additional theoretical basis for FFP or MB-FP clinical infusion for patients, and an innovative research approach for blood transfusion medicine.

\section{Materials and Methods}

\section{Plasma Samples Collection, Processing, and Quality Control} Information

FFP samples $(n=9)$ and MB-FP samples $(n=9)$ were provided by Changchun central blood station. The MB-FP samples are identical to the commercial licensed products in China. All plasma samples are type $\mathrm{O}$ and $\mathrm{RhD}$ positive. The study was approved by the Ethics Committee of the Second Hospital of Jilin University, and written informed consent was obtained from all donors. The MB-FP samples were prepared by MB inactivation equipment with matching plasma membrane filtration, $\mathrm{MB}$ illumination, and MB removal systems, according to the manufacturer instructions (China Shandong Zhongbaokang Medical Equipment Co. Ltd). Briefly, $100 \mathrm{~mL}$ of the plasma, prepared using an integral plasma leukocyte reduction filter, was passed through the instrumentation system containing dry $\mathrm{MB}$ tablets and then into the illumination device. The MB concentration in the plasma was $1 \pm 0.11 \mu \mathrm{M}$, and the plasma was exposed to 30,000-38,000 lx of visible light for 3035 min while being agitated at about $60-80$ cycles per minute at $2-8{ }^{\circ} \mathrm{C}$. Afterwards, the plasma was sent through the $\mathrm{MB}$ removal filter by gravity, and then was entered into a single storage container.

Resulting plasma samples contained stable clotting factors (factors $\mathrm{V}$, VII, X, XI, and XIII contents $\geq 0.7 \mathrm{U} / \mathrm{mL}$ ), plasma protein content $\geq 50 \mathrm{~g} / \mathrm{L}$, and $\mathrm{MB}$ residual quantity $\leq 0.3 \mu \mathrm{mol} / \mathrm{L}$, in accordance with national standards [19]. FFP and MB-FP samples were stored at $-80^{\circ} \mathrm{C}$. When $\mathrm{HBV}, \mathrm{HCV}$, and HIV virus nucleic acid tests were performed on the plasma of 15,756 people, the plasma virus positive rate was $0.152 \%$ ( $23 \mathrm{HBV}$ positive and $1 \mathrm{HIV}$ positive), but no virus was detected in the plasma after $\mathrm{MB} /$ photochemical treatment [20]. The number of residual cells in plasma decreased by 2 orders of magnitude (from $10^{6}$ to $10^{4} /$ unit) after $\mathrm{MB} /$ light virus inactivation, previously reported by Wang [21].

\section{Extraction of Plasma Proteins}

The FFP and MB-FP samples were thawed at $37^{\circ} \mathrm{C}$, and then the proteins with high abundance in plasma were removed using trichloroacetic acid (TCA)/acetone precipitation methods as described previously $[22,23]$. The plasma was centrifuged at $12,000 \mathrm{~g}$ for $5 \mathrm{~min}$, and then the supernatant $(20 \mu \mathrm{L})$ was transferred to a 
Fig. 1.2-DE image comparing the proteins in MB-FP and FFP. Fourteen differentially expressed protein spots were identified between MB-FP and FFP.
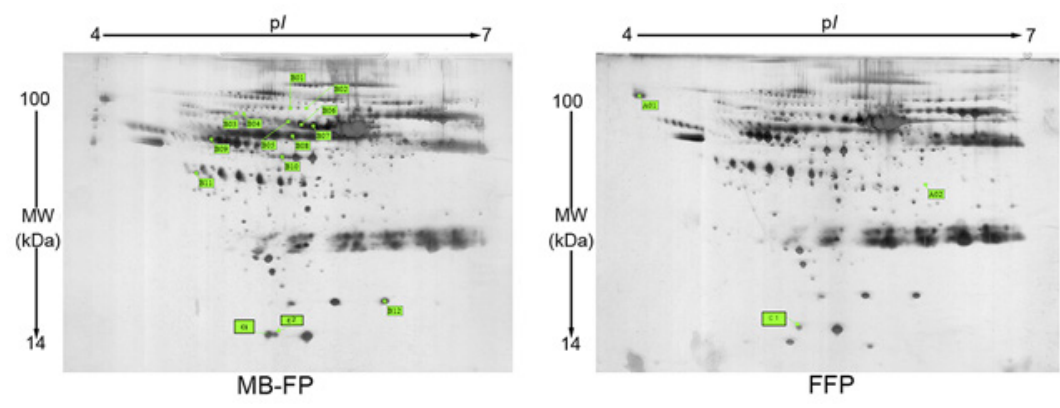

new tube. Four volumes of cold acetone supplemented with $10 \%$ TCA were added to the new tube, and the resulting mixture was placed at $-20^{\circ} \mathrm{C}$ for $90 \mathrm{~min}$. After being centrifuged at $15,000 \mathrm{~g}$ for $20 \mathrm{~min}$, the supernatant was removed to a second tube, and $1 \mathrm{~mL}$ of cold acetone was added to wash the precipitate and incubated on ice for $15 \mathrm{~min}$. After centrifugation, the sediment was dissolved with PBS and washed with cool acetone. The final precipitate was rehydrated and suspended with a freshly prepared solution containing $1.52 \mathrm{~g}$ of thiourea, $4.2 \mathrm{~g}$ of urea, and $0.4 \mathrm{~g}$ of CHAPS per $100 \mathrm{~mL}$ of distilled water. The dissolved protein was stored at $4^{\circ} \mathrm{C}$.

\section{2-DE and Mass Spectrometry}

The protein concentration was determined using a 2-D Quant Kit (GE Healthcare, Chicago, IL, USA) based on the manufacturer instructions. One hundred and twenty-five micrograms of each plasma protein sample in $250 \mu \mathrm{L}$ of rehydration buffer $(7 \mathrm{M}$ urea, $2 \mathrm{M}$ thiourea, $4 \%$ CHAPS, $0.5 \%$ pH 4-7 IPG buffer, 20 mM DTT) containing $0.02 \%$ bromophenol blue was loaded to non-linear $\mathrm{pH}$ 4-7 IPG strips ( $13 \mathrm{~cm}$; GE Healthcare). The IPG strips were rehydrated with protein samples for $15 \mathrm{~h}$ at room temperature. Isoelectric focusing (Bio-Rad Protean IEF Cell system) was performed at $20^{\circ} \mathrm{C}$ with gradually increasing voltages: $100 \mathrm{~V}$ for $120 \mathrm{~min}, 300 \mathrm{~V}$ for $60 \mathrm{~min}, 1,000 \mathrm{~V}$ for $60 \mathrm{~min}$, and then $3,500 \mathrm{~V}$ for $4-5 \mathrm{~h}$. After IEF, the gel strips were reduced using $1 \%$ DTT in equilibration buffer (6 M urea, $50 \mathrm{~mm}$ Tris- $\mathrm{HCl}, 30 \%$ glycerol, $2 \%$ SDS, $0.02 \%$ bromophenol blue) for $15 \mathrm{~min}$ at room temperature with gentle agitation. The strips were then alkylated with $2 \%$ iodoacetamide (GE Healthcare) in equilibration buffer for the second equilibration. The balanced strips were rinsed with $1 \times$ electrophoresis buffer to remove residual solution, and then the strips were transferred to $12.5 \%$ SDS-polyacrylamide gels and sealed with $0.5 \%$ low melting agarose [24]. Electrophoresis was set at $20^{\circ} \mathrm{C}$ and ran at $10 \mathrm{~mA} /$ gel for the first $0.15 \mathrm{~h}$, followed by $20 \mathrm{~mA}$ /gel until the dye front reached the bottom of the gel. Finally, gels were stained with silver nitrate as previously described [25]. Triplicate 2-DE gels were performed for plasma proteins from both FFP and MB-FP samples. Gels were then scanned using ImageScanner (Shanghai Tanon Technology Co. Ltd, Shanghai, China) and differently expressed protein spots between the FFP and MB-FP were analyzed using ImageMaster 2D Platinum 5.0 software (GE Healthcare). The protein spots were calculated using the percentage volume criterion. Fold percentage volume was obtained by dividing the percentage volume of MB-FP spots with that of FFP spots. Protein spots with $\geq 1.5$-fold change and $p<0.05$ were considered significant and selected for further analysis [26].

Each of the differentially expressed protein spots from the 3 replicate 2-DE gels was cut out and transferred to new EP tubes and washed twice with $100 \mu \mathrm{L}$ of distilled water. The liquid was discarded, and the tubes were sealed. The samples were then sent to Guangzhou FitGene Biological Engineering Co. Ltd (Guangzhou, China) for mass spectrometry. The processes were completed according to the methods described by Zhou et al. [26]. Briefly, the gel pieces were destained, dehydrated, and digested using trypsin enzyme. After digestion, the peptides were extracted and processed to MALDI TOF-TOF MS analysis using an ABI 4,800 matrix-assisted laser desorption ionization-time of flight/ time of flight (MALDI-TOF/TOF) proteomics analyzer mass spectrometer (Applied Biosystems, USA). The peptide mass fingerprint data were matched to the NCBInr database using the Profound program under $50 \mathrm{ppm}$ mass tolerance. Proteins were then identified by searching against a comprehensive non-redundant sequence database (NCBInr) using the MASCOT software search engine.

\section{Western Blot}

The plasma protein samples $(20 \mu \mathrm{g})$ were separated by $12 \%$ SDS-PAGE and transferred to PVDF membranes. After blocking with $5 \%$ skimmed milk for $1 \mathrm{~h}$, the membranes were incubated at $4{ }^{\circ} \mathrm{C}$ overnight with anti-Keratin, type II cytoskeletal 1 (KRT1) antibody (1:300, Wuhan Boster Biological Technology Co. Ltd, Wuhan, China), anti-hemopexin (HPX) antibody (1:300, Wuhan Boster Biological Technology Co. Ltd), and anti-glyceraldehyde3-phosphate dehydrogenase (GAPDH) antibody (1:300, Wuhan Boster Biological Technology Co. Ltd), respectively. After 3 washes with washing solution $(20 \mathrm{~mm}$ Tris, $140 \mathrm{mM} \mathrm{NaCl}$, and $0.1 \%$ Tween-20), the membrane was incubated with horseradish peroxidase-conjugated secondary antibody $(1: 1,000)$ at $37^{\circ} \mathrm{C}$ for $2 \mathrm{~h}$. The protein bands were visualized using the enhanced chemiluminescence detection system (Thermo, Rockford, IL, USA).

\section{Enzyme-Linked Immunosorbent Assay}

The levels of HPX in different plasma samples were determined using a Human Hemopexin/HPX ELISA (enzyme-linked immunosorbent assay) Kit (Wuhan Boster Biological Technology Co. Ltd) based on the manufacturer's instructions. There were 3 wells for each plasma sample. Three independent experiments were performed.

\section{Statistical Analysis}

The mass spectrometry report was provided by Guangzhou FitGene Biological Engineering Co. Ltd. The results are reported as the mean \pm SD. GraphPad prism 5 (GraphPad Software, San Diego, CA, USA) was used for the statistical analyses. For the comparison of 2 groups, the Student $t$ test was used. $p<0.05$ was considered statistically significant. 
Table 1. Differentially expressed proteins in MB-FP compared to FFP

\begin{tabular}{|c|c|c|c|c|c|c|c|}
\hline Number & Protein name & Gene name & $\begin{array}{l}\text { Molecular } \\
\text { weight, } \mathrm{kDa}\end{array}$ & Score & Database ID & $\begin{array}{l}\text { Sequence } \\
\text { coverage, \% }\end{array}$ & Change \\
\hline B2 & Conmplement C1r subcomponent & $\mathrm{C} 1 \mathrm{R}$ & 78,047 & 108 & P00736 & 11 & $\uparrow$ \\
\hline B3 & Inter-alpha-trypsin inhibitor heavy chain $\mathrm{H} 4$ & ITI-H4 & 103,521 & 234 & Q14624 & 13 & $\uparrow$ \\
\hline B4 & Keratin, type II cytoskeletal 1 & KRT1 & 66,170 & 230 & P04264 & 24 & $\uparrow$ \\
\hline B5 & Hemopexin & HPX & 52,385 & 427 & P02790 & 43 & $\uparrow$ \\
\hline B6 & Hemopexin & HPX & 52,385 & 379 & P02790 & 37 & $\uparrow$ \\
\hline B10 & Fibrinogen gamma chain & FGG & 50,918 & 254 & P02679 & 35 & $\uparrow$ \\
\hline $\mathrm{C} 1$ & Transthyretin & TTR & 15,991 & 152 & P02766 & 46 & $\uparrow$ \\
\hline $\mathrm{C} 2$ & Transthyretin & TTR & 15,991 & 257 & P02766 & 60 & $\uparrow$ \\
\hline
\end{tabular}

Table 2. The functions and related biological processes of differentially expressed proteins between MB-FP and FFP

\begin{tabular}{|c|c|c|}
\hline $\begin{array}{l}\text { Protein name (gene } \\
\text { name) }\end{array}$ & Functions & Biological processes \\
\hline $\begin{array}{l}\text { Complement C1r } \\
\text { subcomponent (C1R) }\end{array}$ & $\begin{array}{l}\mathrm{C} 1 \mathrm{r} \text { B chain is a serine protease that combines with } \mathrm{C} 1 \mathrm{q} \text { and } \\
\mathrm{C} 1 \mathrm{~s} \text { to form } \mathrm{C} 1 \text {, the first component of the classical pathway } \\
\text { of the complement system }\end{array}$ & $\begin{array}{l}\text { Complement activation } \\
\text { Complement activation, classical pathway } \\
\text { Immune response }\end{array}$ \\
\hline $\begin{array}{l}\text { Inter-alpha-trypsin } \\
\text { inhibitor heavy chain } \mathrm{H} 4 \\
\text { (ITI-H4) }\end{array}$ & $\begin{array}{l}\text { Type II acute phase protein involved in the inflammatory } \\
\text { response to trauma } \\
\text { May also play a role in liver development or regeneration }\end{array}$ & $\begin{array}{l}\text { Acute-phase response } \\
\text { Hyaluronma metabolic process } \\
\text { Platelet degranulation } \\
\text { Response to cytokine }\end{array}$ \\
\hline $\begin{array}{l}\text { Keratin, type II } \\
\text { cytoskeletal } 1 \text { (KRT1) }\end{array}$ & $\begin{array}{l}\text { Regulates the activity of kinases such as PKC and SRC via } \\
\text { binding to integrin beta-1 (ITB1) and the receptor of } \\
\text { activated protein C kinase } 1 \text { (RACK1) }\end{array}$ & $\begin{array}{l}\text { Complement activation, lectin pathway } \\
\text { Cornification } \\
\text { Establishment of skin barrier } \\
\text { Fibrinolysis }\end{array}$ \\
\hline Hemopexin (HPX) & $\begin{array}{l}\text { Binds heme and transports it to the liver for breakdown and } \\
\text { iron recovery, after which the free hemopexin returns to the } \\
\text { circulation }\end{array}$ & $\begin{array}{l}\text { Cellular iron ion homeostasis } \\
\text { Heme metabolic process } \\
\text { Heme transport } \\
\text { Hemoglobin metabolic process }\end{array}$ \\
\hline $\begin{array}{l}\text { Fibrinogen gamma chain } \\
\text { (FGG) }\end{array}$ & $\begin{array}{l}\text { Together with fibrinogen alpha (FGA) and fibrinogen beta } \\
\text { (FGB), polymerizes to form an insoluble fibrin matrix } \\
\text { Has a major function in hemostasis as one of the primary } \\
\text { components of blood clots }\end{array}$ & $\begin{array}{l}\text { Blood coagulation, fibrin clot formation } \\
\text { Cell-matrix adhesion } \\
\text { Cellular protein-containing complex } \\
\text { assembly }\end{array}$ \\
\hline Transthyretin (TTR) & $\begin{array}{l}\text { Thyroid hormone-binding protein } \\
\text { Probably transports thyroxine from the bloodstream to the } \\
\text { brain }\end{array}$ & $\begin{array}{l}\text { Cellular protein metabolic process } \\
\text { Extracellular matrix organization } \\
\text { Neutrophil degranulation }\end{array}$ \\
\hline
\end{tabular}

\section{Results}

\section{Analysis of Differentially Expressed Proteins}

The proteins of MB-FP and FFP were separated and detected by $2-\mathrm{DE}$, and the representative images of $2-\mathrm{DE}$ are shown in Figure 1. After analysis, the protein matching rate of MB-FP and FFP was more than $80 \%$, which indicated that the electrophoretic gel maps have good reproducibility and can be used to analyze differentially expressed protein spots. Compared to FFP, MB-FP had 14 differentially expressed protein spots (Fig. 1).
After processing the differentially expressed protein spots using mass spectrometry, 8 differentially expressed spots were obtained and 6 differentially expressed proteins were identified (Table 1), including complement C1r subcomponent (C1R), inter-alpha-trypsin inhibitor heavy chain H4 (ITI-H4), KRT1, HPX, FGG, and TTR. The locally magnified 2-DE maps of differentially expressed protein spots (B2, B3, B4, B5, B6, B10, C1, and $\mathrm{C} 2$ ) are displayed in Figure 2. The functions and related biological processes of the 6 differentially expressed proteins are shown in Table 2. 

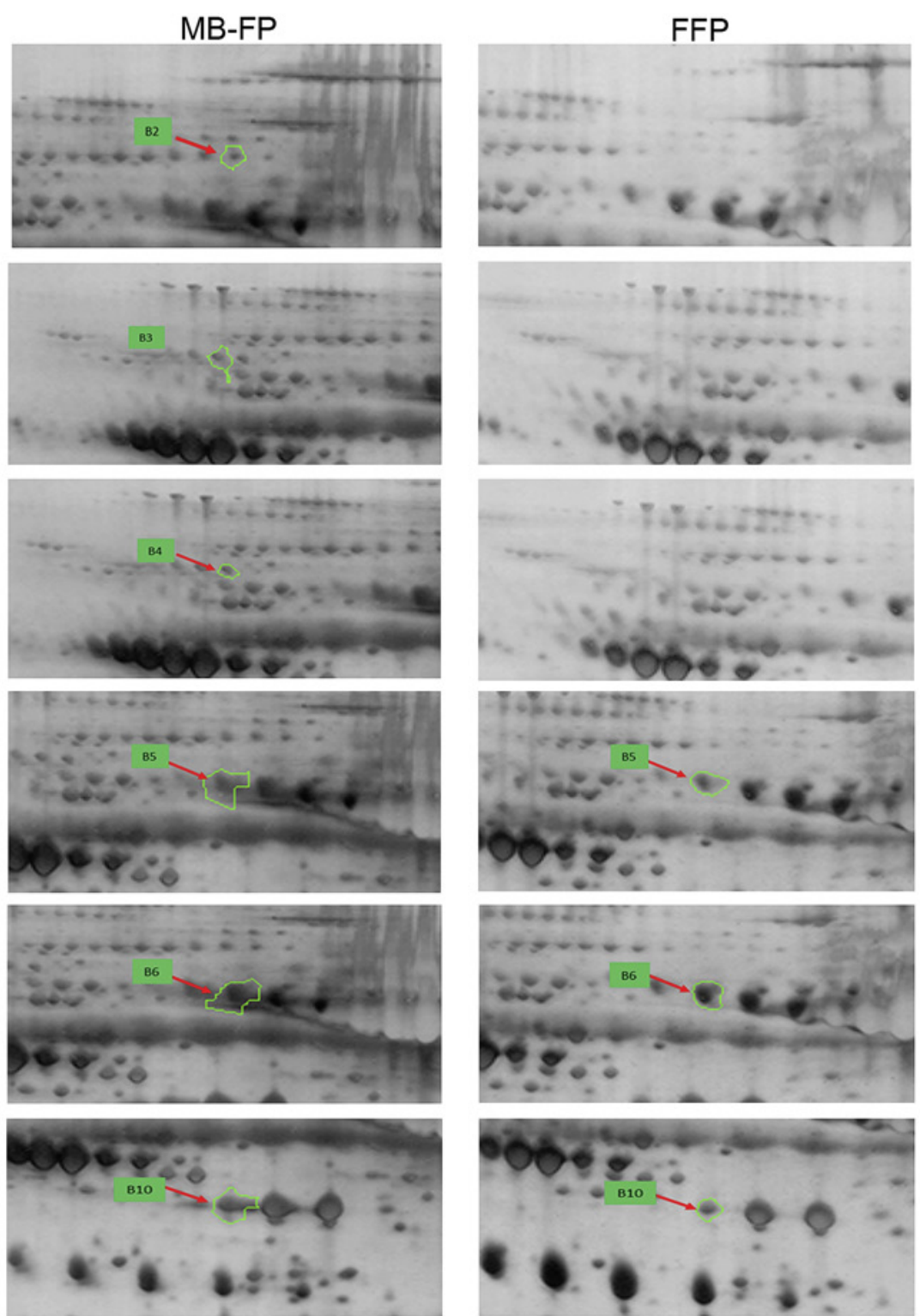

Fig. 2. Differentially expressed protein spots (B2, B3, B4, B5, B6, B10, C1, and C2) observed in locally magnified 2-DE maps.
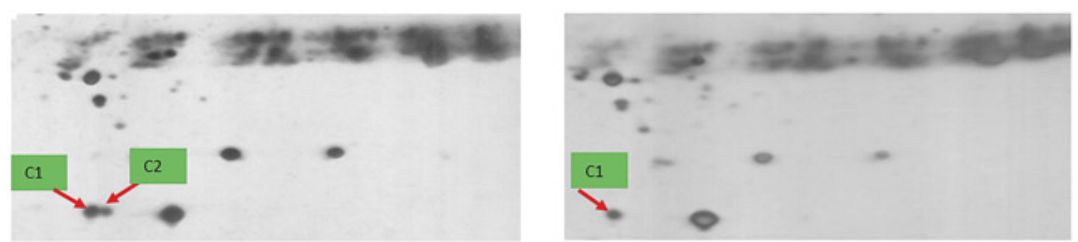

Verification of Differentially Expressed Proteins

The differentially expressed proteins, KRT1 and HPX, were chosen to verify their expression levels in MB-FP and FFP using Western blot and ELISA. The representative images of KRT1 and HPX expression using Western blot are shown in Figure 3a. The grey analyses showed no significant difference in the expression level of KRT1 between MB-FP and FFP ( $p>0.05$, Fig. $3 b)$, which was not consistent with the results from 2-DE maps. For HPX, its expression was significantly higher in FFP than in MB-FP $(p<0.05$, Fig. 3c).

ELISA was utilized to detect the concentrations of HPX in the MB-FP and FFP. The concentration of HPX in FFP was significantly higher than in MB-FP $(p<0.05$, Fig. 4). This was in accordance with the results from Western blot. Therefore, both Western blot and ELISA results indicated the loss of HPX in MB-FP. 
Fig. 3. The protein expression levels of keratin, KRT1, HPX, and anti-GAPDH in MB-FP and FFP determined by Western blot. A The images of KRT1 and HPX expression determined by Western blot. M, marker; $1-4$, proteins from FFP; $5-8$, proteins from MB-FP. The grey analysis of KRT1 (B) and HPX (C) proteins. ${ }^{*} p<0.05$ compared to the MB-FP group.

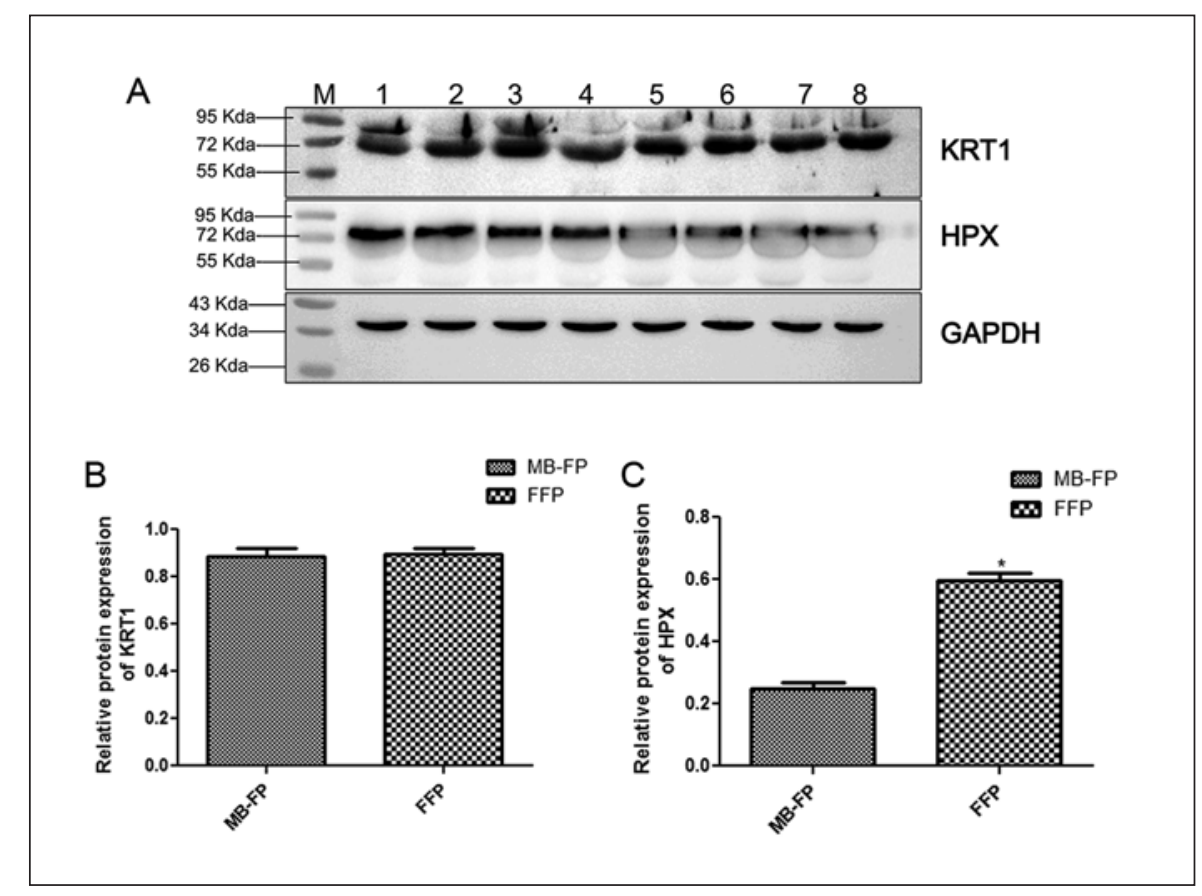

In summary, MB-FP could cause changes in plasma proteins and corresponding changes in electrophoresis patterns. Modified proteins include C1R, ITI-H4, KRT1, HPX, FGG, and TTR. For the first 4 modified proteins, we are the first to discover and document their changes in MB-FP.

\section{Discussion}

Plasma infusion is an important part of clinical treatment. Given their long-term safety, MB/light-treated plasma is widely used in clinical practice. Compared to FFP, MB-processed plasma can reduce the incidence of adverse events in high-risk countries and reduce the spread of serious viral infections, including emerging infectious diseases transmitted through blood transfusion $[12,27,28]$. Previous studies have focused on the changes of coagulation factors, plasma protein contents, and corresponding biochemical indicators after clinical infusion of FFP and MB-FP [14-16, 28]. However, few studies have reported changes in other plasma protein components between FFP and MB-FP [18, 29, 30]. Expanding on previous research, we have discovered several novel differentially expressed proteins between FFP and MB$\mathrm{FP}$ at the proteomic level through 2-DE and mass spectrometry. The 6 differentially expressed proteins identified include C1R, ITI-H4, KRT1, HPX, FGG, and TTR. The expression of these proteins in MB-FP appears to have increased. However, subsequent detection of HPX and KRT1 using ELISA and/or Western blot failed to



Fig. 4. The concentrations of HPX in MB-FP and FFP were measured using ELISA. ${ }^{*} p<0.05$ compared to the MB-FP group.

confirm this difference. These results indicate that MB/ light treatment can modify the protein components in plasma.

$\mathrm{MB}$ is a thiazine-based basic dye that is now widely used to inactivate virus in plasma. Crettaz et al. [18] previously reported that FGG, TTR, and apolipoprotein A-I were significantly modified in MB-FP. In addition to FGG and TTR, our results also revealed 4 additional modifications in plasma proteins, including C1R, ITI-H4, KRT1, and HPX. C1R, an important component of the complement system, participates in the complement activation pathway, as well as in inflammatory and adaptive

Alterations in MB-FP 
immune responses [31]. ITI-H4, a 120-kDa acute-phase glycoprotein, is involved in the inflammatory response of trauma. In addition, ITI-H4 has been reported to be associated with the occurrence of tumors [32]. ITI-H4 may become a potential therapeutic target that could inhibit cancer metastasis, as well as a prognostic marker for patients [33]. FGG can form an insoluble fibrin matrix when combined with alpha chain and beta chain, which plays a role in blood clot and fibrin clot formation, as well as hemostasis [34]. Cardigan et al. [35] previously reported that MB treatment resulted in a $10 \%$ reduction in endogenous thrombin potential and 30\% decrease in peak thrombin, as well as an expected $20-35 \%$ loss of Factor (F)VIII, fibrinogen, and FXI activity, but MB treatment has very little effect on the rate and the strength of clot formation as assessed using thromboelastometry. The FGG modifications we observed may explain or be related to the above results of Cardigan et al. [35]. TTR is not only a plasma protein, but also a carrier protein that can transport thyroid hormones and retinols [36]. KRT1, an essential component of the cytoskeleton, can activate carbohydrate binding receptor and participate in the lectin pathway [37]. Western blot results showed that KRT1 was determined both in MB-FP and FFP with no significant difference, but it was detected only in MB-FP using 2-DE maps. A possible explanation is that the level of KRT1 in plasma is low, which is due to low levels of plasma particles and residual cells in plasma. Another explanation may be that Western blot detection is more sensitive than 2-DE and amplifies protein signals. HPX is mainly produced in the liver, and partially expressed in the central and peripheral nervous system, skeletal muscle, retina, and kidney [38]. HPX can promote the metabolism of heme and iron, thus protecting the body from oxidative damage [39]. In our research, the HPX level was significantly lower in MB-FP than in FFP, as revealed by both Western blot and ELISA. These results suggest that $\mathrm{MB} /$ light treatment caused a decrease in HPX. But why was the decrease in HPX inconsistent with the high level of HPX shown using 2-DE maps? Despite the overall low level of HPX in MB-FP, we speculate that the high level of HPX shown using 2-DE maps accounted for one of the HPX isoforms, which may have been modified by MB/ light treatment. Therefore, these protein modifications in MB-FP caused by MB/light treatment may have important clinical implications.

Evidenced by many publications on its quality and application in current clinical use, MB/light-treated plasma is considered to be highly safe and widely used. However, current knowledge is limited regarding what kinds of proteins in plasma can be changed by the process of $\mathrm{MB} /$ light treatment while inactivating plasma viruses. On the one hand, the changes in plasma protein caused by $\mathrm{MB} /$ light treatment can promote researchers to improve the method of MB/light treatment of plasma, such as adding other viral inhibitors to reduce the amount of MB. On the other hand, we can further study whether the plasma protein changes are related to the specific disease of the plasma transfusion patient and adjust the treatment plan accordingly.

In conclusion, this comparative proteomics study revealed that $\mathrm{MB} /$ light treatment modifies plasma proteins, such as C1R, ITI-H4, KRT1, HPX, FGG, and TTR. Future research may benefit from studying the exact modification of these proteins and the effects of these modified proteins on their functions and utilities in clinical plasma infusion.

\section{Statement of Ethics}

The experiment was approved by the Ethics Committee of the Second Hospital of Jilin University, and written informed consent was obtained from all donors.

\section{Conflict of Interest Statement}

The authors have no conflicts of interest to declare.

\section{Funding Sources}

There are no funding sources to declare.

\section{Author Contributions}

T.W. and J.L. designed the research study. T.W., X.W., and K.R. conducted the experiment and obtained the data. K.R. and X.H. analyzed and interpreted the results. T.W. drafted the manuscript, and J.L. provided revisions. All authors read and approved the final version.

\section{References}

1 Horsey PJ. Blood transfusion and surgery. Br Med J. 1985 Jul;291(6490):234.

2 Cap AP, Beckett A, Benov A, Borgman M, Chen J, Corley JB, et al. Whole blood transfusion. Mil Med. 2018 Sep;183 suppl_2:44-51.

3 Verma A, Hemlata. Blood component therapy. Indian J Pediatr. 2008 Jul;75(7):717-22.

4 Watson JJ, Pati S, Schreiber MA. Plasma transfusion: history, current realities, and novel improvements. Shock. 2016 Nov;46(5): 468-79.

5 Green L, Bolton-Maggs P, Beattie C, Cardigan R, Kallis Y, Stanworth SJ, et al. British Society of Haematology Guidelines on the spectrum of fresh frozen plasma and cryoprecipitate products: their handling and use in various patient groups in the absence of major bleeding. Br J Haematol. 2018 Apr;181(1):54-67. 
6 Cushing MM, Pagano MB, Jacobson J, Schwartz J, Grossman BJ, Kleinman S, et al.; AABB Clinical Transfusion Medicine Committee. Pathogen reduced plasma products: a clinical practice scientific review from the AABB. Transfusion. 2019 Sep;59(9):2974-88.

7 Rock G. A comparison of methods of pathogen inactivation of FFP. Vox Sang. 2011 Feb; 100(2):169-78

8 Larrea L, Ortiz-de-Salazar MI, Martínez P, Roig R. Quantitative analysis of plasma proteins in whole blood-derived fresh frozen plasma prepared with three pathogen reduction technologies. Transfus Apheresis Sci. 2015 Jun;52(3):305-10.

9 Garraud O. Are all therapeutic plasma preparations the same: is it worth assessing them in clinical trials? Transfus Apheresis Sci. 2017 Dec;56(6):920-3.

10 Wasiluk T, Rogowska A, Boczkowska-Radziwon B, Zebrowska A, Bolkun L, Piszcz J, et al. Maintaining plasma quality and safety in the state of ongoing epidemic - The role of pathogen reduction. Transfus Apher Sci. 2020, Online ahead of print.

11 Tuite EM, Kelly JM. Photochemical interactions of methylene blue and analogues with DNA and other biological substrates. J Photochem Photobiol B. 1993 Dec;21(2-3):103-24.

12 Lozano M, Cid J, Müller TH. Plasma treated with methylene blue and light: clinical efficacy and safety profile. Transfus Med Rev. 2013 Oct:27(4):235-40.

13 Steinmann E, Gravemann U, Friesland M, Doerrbecker J, Müller TH, Pietschmann T, et al. Two pathogen reduction technologies methylene blue plus light and shortwave ultraviolet light - effectively inactivate hepatitis $\mathrm{C}$ virus in blood products. Transfusion. 2013 May;53(5):1010-8.

14 Backholer L, Wiltshire M, Proffitt S, Cookson P, Cardigan R. Paired comparison of methylene blue- and amotosalen-treated plasma and cryoprecipitate. Vox Sang. 2016 May; 110(4):352-61

15 Thiele T, Hron G, Kellner S, Wasner C, Westphal A, Warkentin TE, et al. Thrombin generation, ProC $\left({ }^{\circledR}\right)$ Global, prothrombin time and activated partial thromboplastin time in thawed plasma stored for seven days and after methylene blue/light pathogen inactivation. Blood Transfus. 2016 Jan;14(1):66-72.

16 Zeiler T, Riess H, Wittmann G, Hintz G, Zimmermann R, Müller $\mathrm{C}$, et al. The effect of methylene blue phototreatment on plasma proteins and in vitro coagulation capability of single-donor fresh-frozen plasma. Transfusion. 1994 Aug;34(8):685-9.
17 Garwood M, Cardigan RA, Drummond O, Hornsey VS, Turner CP, Young D, et al. The effect of methylene blue photoinactivation and methylene blue removal on the quality of fresh-frozen plasma. Transfusion. 2003 Sep; 43(9):1238-47.

18 Crettaz D, Sensebe L, Vu DH, Schneider P, Depasse F, Bienvenut WV, et al. Proteomics of methylene blue photo-treated plasma before and after removal of the dye by an absorbent filter. Proteomics. 2004 Mar;4(3):88191.

19 Ministry of Health of the People's Republic of China. Chinese quality requirement for whole blood and blood components. 2012. GB 18469-2012.

20 Rong Li HC. Xian Qian Preparation of virus inactivated plasma by methylene blue photochemical method and evaluation of its effect on clinical application. J Clin Transfus Lab Med. 2013;15(1):4-6.

21 Wang C. Effect of methylene blue/photochemical virus inactivation on plasma components and white blood cell residual. J Clin Transfusion Lab Med. 2014;2014(3):290-2.

22 Chen YY, Lin SY, Yeh YY, Hsiao HH, Wu CY, Chen ST, et al. A modified protein precipitation procedure for efficient removal of albumin from serum. Electrophoresis. 2005 Jun; 26(11):2117-27.

23 Hao R, Adoligbe C, Jiang B, Zhao X, Gui L, Qu $\mathrm{K}$, et al. An optimized trichloroacetic acid/acetone precipitation method for two-dimensional gel electrophoresis analysis of qinchuan cattle longissimus dorsi muscle containing high proportion of marbling. PLoS One. 2015 Apr;10(4):e0124723.

24 Zhan X, Huang Y, Long Y. Two-dimensional gel electrophoresis coupled with mass spectrometry methods for an analysis of human pituitary adenoma tissue proteome. J Vis Exp. 2018 Apr;134:56739.

25 Hochstrasser DF, Harrington MG, Hochstrasser AC, Miller MJ, Merril CR. Methods for increasing the resolution of two-dimensional protein electrophoresis. Anal Biochem. 1988 Sep;173(2):424-35.

26 Zhou DH, Zhao FR, Huang SY, Xu MJ, Song $\mathrm{HQ}, \mathrm{Su} \mathrm{C}$, et al. Changes in the proteomic profiles of mouse brain after infection with cyst-forming Toxoplasma gondii. Parasit Vectors. 2013 Apr;6(1):96.

27 Politis C, Kavallierou L, Hantziara S, Parara M, Zervou E, Katsarou O, et al. Haemovigilance data on the use of methylene blue virally inactivated fresh frozen plasma with the Theraflex MB-Plasma System in comparison to quarantine plasma: 11 years' experience. Transfus Med. 2014 Oct;24(5):316-20.
28 Gravemann U, Handke W, Sumian C, Alvarez I, Reichenberg S, Müller TH, et al. Plasma temperature during methylene blue/light treatment influences virus inactivation capacity and product quality. Vox Sang. 2018 May; 113(4):368-77.

29 Wieding JU, Hellstern P, Köhler M. Inactivation of viruses in fresh-frozen plasma. Ann Hematol. 1993 Dec;67(6):259-66

30 Suontaka AM, Blombäck M, Chapman J. Changes in functional activities of plasma fibrinogen after treatment with methylene blue and red light. Transfusion. 2003 May;43(5): 568-75.

31 Almitairi JO, Venkatraman Girija U, Furze CM, Simpson-Gray X, Badakshi F, Marshall JE, et al. Structure of the C1r-C1s interaction of the $\mathrm{C} 1$ complex of complement activation. Proc Natl Acad Sci USA. 2018 Jan;115(4): 768-73.

32 Huang M, Zhang W, Zhao B, Li L. Relationship between inter- $\alpha$-trypsin inhibitor heavy chain 4 and ovarian cancer. Chin J Cancer Res. 2019 Dec;31(6):955-64.

33 Lee EJ, Yang SH, Kim KJ, Cha H, Lee SJ, Kim $\mathrm{JH}$, et al. Inter-alpha inhibitor $\mathrm{H} 4$ as a potential biomarker predicting the treatment outcomes in patients with hepatocellular carcinoma. Cancer Res Treat. 2018 Jul;50(3):64657.

34 Mosesson MW. Fibrinogen gamma chain functions. J Thromb Haemost. 2003 Feb;1(2): 231-8.

35 Cardigan R, Philpot K, Cookson P, Luddington $\mathrm{R}$. Thrombin generation and clot formation in methylene blue-treated plasma and cryoprecipitate. Transfusion. 2009 Apr;49(4): 696-703.

36 Ciccone L, Fruchart-Gaillard C, Mourier G, Savko M, Nencetti S, Orlandini E, et al. Copper mediated amyloid- $\beta$ binding to Transthyretin. Sci Rep. 2018 Sep;8(1):13744.

37 Petrosyan A, Ali MF, Cheng PW. Keratin 1 plays a critical role in golgi localization of core $2 \mathrm{~N}$-acetylglucosaminyltransferase $\mathrm{M}$ via interaction with its cytoplasmic tail. J Biol Chem. 2015 Mar;290(10):6256-69.

38 Tolosano E, Altruda F. Hemopexin: structure, function, and regulation. DNA Cell Biol. 2002 Apr;21(4):297-306

39 Tolosano E, Fagoonee S, Morello N, Vinchi F, Fiorito V. Heme scavenging and the other facets of hemopexin. Antioxid Redox Signal. 2010 Feb;12(2):305-20. 